\title{
ЕКОНОМІЧНА ДІАГНОСТИКА СТАНУ ТА ПЕРСПЕКТИВИ ДІЯЛЬНОСТІ ПІДПРИЄМСТВ ТРАНСПОРТНОЇ ГАЛУЗІ РЕГІОНУ
}

\author{
Машканцева Світлана Олександрівна \\ кандидат економічних наук, доцент \\ Національний університет «Одеська морська академія» (м. Одеса, Україна) \\ volodymyr@wiktoriya.com
}

У статті розглянуто стан діяльності підприємств транспортної галузі регіону за допомогою аналізу показників обсягу вантажів, вантажообігу, середньої відстані перевезень, довжини залізничних колій та автомобільних доріг загального користування за регіонами. Запропоновано заходи щодо забезпечення подальшого розвитку підприємств транспортної галузі на регіональному рівні. Обгрунтовано, що сучасний стан функціонування підприємств транспортної галузі характеризується як кризовий, що значно актуалізує питання економічної діагностики діяльності підприємств у регіонах України. Це зумовлює необхідність змістовного аналізу стану розвитку підприємств транспортної галузі, виявлення зон ризику та розробки комплексу антикризових заходів.

Ключові слова: вантажообіг, діагностика, залізничний транспорт, автомобільний транспорт, транспортна галузь, регіон, морський і річковий транспорт.

DOI: https://doi.org/10.32845/bsnau.2019.3.22

Постановка проблеми у загальному вигляді та ї зв'язок із важливими науковими чи практичними завданнями. Інтеграція українського транспортного комплексу в Європейську транспортну систему розпочалася зі вступу України до міжнародних транспортних організацій і структур, ратифікації низки міжнародних угод, конвенцій та інших документів з питань організації транспортної галузі. Відповідно до європейських стандартів українська транспортна система має відповідати вимогам якості, регулярності, надійності надання транспортних послуг, безпеки перевезення вантажів та пасажирів, швидкості і вартості доставки, енерго-ефективності та показників техногенного навантаження на навколишнє природне середовище. Регіональні особливості геополітичного положення України сприяють формуванню міждержавного значення транспортної галузі. Моніторинг діяльності суб'єктів господарювання $є$ одним з пріоритетних дієвих методів управління, основним елементом обґрунтування управлінських рішень. Діагностика стану господарської діяльності підприємств транспортної галузі передбачає всебічне вивчення обсягу вантажних перевезень, вантажообігу, середньої відстані перевезень, довжини залізничних колій та автомобільних доріг загального користування за регіонами. При цьому діагностика грунтується на результатах аналізу і виступає як обгрунтована та достовірна процедура, від якої залежить подальший напрям розвитку підприємств транспортної галузі.

Аналіз останніх досліджень і публікацій, в яких започатковано розв'язання даної проблеми і на які спирається автор, виділення невирішених раніше частин загальної проблеми, котрим присвячується означена стаття.

Проблематика аналізу стану та розвитку підприємств транспортної галузі, вивчалась в працях: О. Бакаєва, В. Сергєєва, Л. Миротіна, В. Назаренко, Ю. Неруша, Д. Ніколаєва, О. Проценко. Наукові розробки Н. Правдина, В. Подкопаєва, Г. Левікова, В. Тарабанько, Л. Савченко присвячені проблемам використання транзитного потенціалу України та організації інтер- і мультимодальних перевезень вантажів. Проте, в умовах сьогодення питання функціонування підприємств транспортної галузі потребує поглиблення наукових досліджень для розробки пропозицій щодо формування потужної ефективної транспортної галузі саме на регіональному рівні.

Формулювання цілей статті (постановка завдання). Метою статті $€$ аналітична оцінка стану функціонування підприємств транспортної галузі регіону для розробки та обґрунтування пропозицій щодо перспектив їх інноваційного розвитку в сучасних умовах.

Виклад основного матеріалу дослідження 3 повним обґрунтуванням отриманих наукових результатів. Транспортна галузь займає особливе місце у розвитку всіх секторів економіки, забезпечуючи при цьому просування матеріальних потоків у макрологістичних ланцюгах. Основним завданням функціонування транспортної галузі регіону є своєчасне, якісне та повне задоволення потреб споживачів (галузей економіки та населення) у перевезеннях, підвищення конкуренто-спроможності надання транспортних послуг. За останніх десять років стан транспортної галузі України в цілому та її регіонів характеризується як нестабільний (табл. 1).

Динаміка обсягів перевезення вантажів за видами транспорту України, млн.т

\begin{tabular}{|c|c|c|c|c|c|c|c|c|}
\hline \multirow{2}{*}{ Вид транспорту } & \multicolumn{6}{|c|}{ Роки } & \multirow{2}{*}{$\begin{array}{l}\text { 2018p. в \% } \\
\text { до 2010p. }\end{array}$} & \multirow{2}{*}{$\begin{array}{l}2018 p . \text { в } \% \\
\text { до 2014p. }\end{array}$} \\
\hline & 2010 & 2014 & 2015 & 2016 & 2017 & 2018 & & \\
\hline $\begin{array}{c}\text { Транспорт, всього } \\
\text { у тому числі: }\end{array}$ & 1765 & 1623 & 1474 & 1543 & 1582 & 1643 & 93,1 & 101,2 \\
\hline залізничний & 433 & 386 & 350 & 343 & 339 & 322 & 74,4 & 83,4 \\
\hline морський & 4 & 3 & 3 & 3 & 2 & 2 & 50,0 & 66,7 \\
\hline річковий & 7 & 3 & 3 & 4 & 4 & 4 & 57,1 & 133,3 \\
\hline автомобільний & 1168 & 1131 & 1021 & 1086 & 1122 & 1206 & 103,3 & 106,6 \\
\hline трубопровідний & 153 & 100 & 97 & 107 & 115 & 109 & 71,2 & 109,0 \\
\hline авіаційний & 0,1 & 0,1 & 0,1 & 0,1 & 0,1 & 0,1 & 100,0 & 100,0 \\
\hline
\end{tabular}

*розраховано за даними Державної служби статистики України [1] 
Результати діяльності підприємств транспортної галузі протягом 2010-2018 рр. свідчать про наявність ознак зниження їх ділової активності. Так, обсяги перевезення вантажів в 2018 році порівняно з 2010 роком скоротились на 6,9%. При цьому суттєве зменшення характерне для залізничного транспорту - на 25,6\%; морського - на $50 \%$; річкового - на $42,9 \%$ та трубопровідного відповідно на 28,8 \%. Такий стан галузі викликаний впливом кризової ситуації, яка в значній мірі позначилася на падінні обсягів промислового виробництва внаслідок кон'юнктури зовнішніх ринків, що мають тренд погіршення та зниженням обсягів внутрішнього попиту при зменшенні купівельної спроможності. Проте, обсяги перевезення автомобільним транспортом за аналізований період збільшились на 3,3 \%.

Залізничний транспорт - виробничо-технологічний комплекс підприємств залізничного транспорту, призначений для забезпечення потреб суспільного виробництва і населення країни в перевезеннях у внутрішньому і міжнародному сполученнях та надання інших транспортних послуг усім споживачам без обмежень за ознаками форми власності та видів діяльності [2, с. 89].

За обсягами вантажних перевезень залізниці України займають четверте місце на Євразійському континенті, оступаючись лише залізницям Китаю, Росії та Індії. Мережа залізничних магістралей характерна для правобережного Лісостепу та західних територій України, Донбасу, Придніпров'я. Найбільш забезпечені залізничною колією області: Донецька, Львівська, Чернівецька. Територіально залізничний транспорт поділено на шість залізниць: Південно-Західну (центрКиїв), Львівську, Південну (Харків), Донецьку, Придніпровську (Дніпропетровськ), Одеську. Внутрішні магістралі: ДонбасКривий Ріг, Харків-Севастополь, Київ-Львів, Львів-Одеса, Харків-Нижньодніпровськ-Херсон.

Автомобільний транспорт за рахунок високої мобільності, великої різноманітності транспортних засобів за вантажопідйомністю, грузоємкістю, призначенням, конструктивним і економічним характеристиками має велике значення для перевезення на короткі відстані. Від якості роботи автомобільного транспорту залежить життєдіяльність міст та селищ. Протягом 2014-2018 років обсяги перевезення вантажів автотранспортними підприємствами зросли на 2,5\%.

Логутова Т. Г., Полторацький М.М. визначили такі ключові проблеми розвитку залізничного та автомобільного транспорту:

- формування конкурентного середовища на ринках перевезень;

- збереження стійкості роботи в кризисних умовах;

- впровадження новітніх економічних підходів до тарифоотворення;

- залучення у державні програми розвитку іноземних інвесторів на привабливих умовах;

- впровадження ефективних моделей державно-приватного партнерства;

- підвищення якості транспортних послуг [3, с. 10].

Водний транспорт $є$ багатофункціональною структурою, що задовольняє потребам національної економіки у транспортному забезпеченні. Морські та річкові порти є складовою частиною транспортної та виробничої інфраструктури держави. Від ефективності функціонування портів, рівня їх технологічного та технічного оснащення, відповідності сис- теми управління та розвитку інфрраструктури сучасним міжнародним вимогам залежить конкурентоспроможність вітчизняного транспортного комплексу на світовому ринку [4].

Головними перевагами морського транспорту є:

- високий експортний потенціал вантажів чорних металів, вугілля, залізорудного концентрату та зернових;

- наявність потужностей з обробки вантажів;

- вигідне розташування морських портів для забезпечення транзитних вантажопотоків;

- наявність нормативно-правової бази щодо можливості залучення приватних інвестицій для розвитку портової галузі;

- наявність висококваліфікованих спеціалістів портової галузі.

Так, Дунайські порти (Рені, Ізмаїл, Усть-Дунайськ) обслуговують вантажопотоки сьомого (Критського) транспортного коридору та вантажопотоки з Донбасу та Поволжя у країни Придунав'я та Центральної Європи. Азовські порти (Бердянськ, Маріуполь) здійснюють транспортне обслуговування промислових центрів Донбасу та беруть участь у перевезеннях експортних вантажів у країни Середземномор'я, Придунав'я, Центральної Європи. Порти Північно-Західного Причорномор'я (Білгород-Дністровський, Іллічівськ, Одеса, Южний, Октябрьськ, Миколаїв, Херсон, Скадовськ) забезпечують транспортування зовнішньоторговельних та транзитних потоків масових вантажів далеких напрямків; обслуговують вантажопотоки Євразійського транспортного коридору (включаючи нафтовантажі). Найбільш значними з цих портів $€$ Іллічівськ, Одеса та Южний. На їхню частку сумарно припадає близько $60 \%$ усього вантажообігу українських морських портів [5].

Річкові порти України відіграють значну роль в системі міжнародних транспортних транзитних коридорів, оскільки особлива роль більшості портів визначається тим, що вони можуть бути прямими учасниками міжнародних логістичних систем. До складу АСК «УКРРІЧФЛОТ» входять 5 найбільших річкових порти: Дніпропетровський, Запорізький, Нікопольський, Херсонський, Миколаївський. 3 річкові порти (Дніпропетровський, Запорізький, Нікопольський) розташовані в промислових регіонах, які $є$ експортностворюючими і слугують воротами для імпортних потоків. 2 річкові порти (Херсонський і Миколаївський), які розташовані в гирлах Дніпра і Південного Бугу, не обмежені міжнавігаційним періодом та спеціалізуються на стандартних видах портових послуг, рейдових перевантаженнях.

Річний порт Київський призначений для транспортування виробів машинобудування, металобрухту, лісу, продукцію легкої і харчової промисловості. Основними портами, де відбувається перевантаження з річкового на залізничний транспорт, є Дніпропетровськ, Запоріжжя, Черкаси, Кременчук [6].

В Україні доцільно реформування річкової галузі з метою перенесення частини вантажопотоків з автошляхів та залізниці на річки, а також розвитку річкової логістики та інфраструктури. Влада країни та провідні підприємства різних форм власності, які мають безпосереднє відношення до перевезень річковим транспортом, приділяють цьому питанню значну увагу, оскільки контейнеризація вантажів - це, по-перше, незайнята ніша, а по-друге, це світовий тренд, який має стійку тенденцію до зростання, і на сьогоднішній день $€$ найбільш зручним та економічним способом перевезення за рахунок універсальності, мультимодальності та надійності. 
Діяльність авіаційного транспорту впливає на розвиток світового господарства, забезпечуючи зв'язок та комунікацію між країнами та регіонами світу, стимулює зростання зовнішньоекономічного співробітництва, сприяє міжнародній торгівлі, створює робочі місця тощо [7]. Розвинена авіаційна галузь сприяє підвищенню інвестиційної привабливості країни і розширенню можливостей для діяльності на її території міжнародних компаній. Трубопровідний транспорт є найбільш економічним і ефективним для транспортування рідкого палива, пального і технологічного газу, хімічних продуктів. Його особливостями є відсутність рухомого складу, постійний режим роботи незалежно від стану погоди та кліматичних умов, простота в експлуатації та режимі управління перевезеннями. Так, у 2018 році порівняно з 2010 роком обсяги перевезення вантажів трубопровідним транспортом зменшились на 28,8 \%, проте, в 2018 році порівняно з 2014 роком зросли на $9 \%$.

В 2018 році порівняно з 2010 роком вантажообіг в цілому за всіма видами транспорту зменшився на 13,7 \%, що пов'язано з деактивізацією виробничої діяльності внутрішньо орієнтованих галузей промисловості та з зменшенням попиту на послуги вантажного транспорту. Так, вантажообіг залізничного транспорту за останні десять років зменшився на
14,6\%, морського відповідно на $65,4 \%$, річкового на $57,9 \%$, авіаційного на $25 \%$, трубопровідного на 27,7 \%. Проте, стосовно автомобільного транспорту, то цей показник збільшився на $33,8 \%$.

На обсяг вантажообігу всіх видів транспорту впливають обсяг вантажу і середня відстань його перевезень. Середня відстань перевезення однієї тони вантажів автомобільним транспортом значно зросла в Волинській області на 23,4 \%, в Закарпатській області - в 2,5 рази, Чернівецькій на 41,3 $\%$, проте цей показник зменшився в Івано-Франківській області на 23,5\%, Тернопільській на $30 \%$.

В галузі залізничного транспорту показник експлуатаційної довжини залізничних колій загального користування за областями представлено в таблиці 2. Інформація таблиці 2 показує, що в основному експлуатаційна довжина залізничних колій загального користування України зменшилась на 1918 км або на 8,9 \%. Так, в цей показник збільшився в Харківській області на 0,4 \%, в усіх інших областях він зменшився в середньому на $2 \%$. Отже, технічні стандарти функціонування залізничного транспорту модернізуються відповідно до міжнародних стандартів.

Експлуатаційна довжина залізничних колій загального користування за регіонами (на кінець року, км)*

\begin{tabular}{|c|c|c|c|c|c|c|}
\hline \multirow{2}{*}{ Адміністративно-територіальні одиниці } & \multicolumn{6}{|c|}{ Роки } \\
\hline & 2010 & 2014 & 2015 & 2016 & 2017 & 2018 \\
\hline Автономна Республіка Крим & 629 & - & - & - & - & - \\
\hline Вінницька & 1074 & 1074 & 1074 & 1074 & 1074 & 1074 \\
\hline Волинська & 597 & 593 & 593 & 593 & 593 & 593 \\
\hline Дніпропетровська & 1558 & 1554 & 1554 & 1554 & 1554 & 1554 \\
\hline Донецька & 1591 & 1570 & 1570 & 1570 & 936 & 936 \\
\hline Житомирська & 1013 & 1016 & 1016 & 1016 & 1016 & 1016 \\
\hline Закарпатська & 606 & 598 & 602 & 602 & 602 & 602 \\
\hline Запорізька & 990 & 988 & 988 & 988 & 988 & 988 \\
\hline Івано-Франківська & 496 & 494 & 494 & 494 & 494 & 494 \\
\hline Київська & 792 & 798 & 798 & 798 & 798 & 798 \\
\hline Кіровоградська & 892 & 893 & 893 & 893 & 893 & 893 \\
\hline Луганська & 1092 & 1092 & 1092 & 1092 & 544 & 544 \\
\hline Львівська & 1280 & 1263 & 1263 & 1263 & 1263 & 1263 \\
\hline Миколаївська & 711 & 711 & 711 & 711 & 711 & 707 \\
\hline Одеська & 1068 & 1061 & 1044 & 1044 & 1044 & 1044 \\
\hline Полтавська & 852 & 835 & 852 & 852 & 852 & 852 \\
\hline Рівненська & 585 & 577 & 579 & 578 & 578 & 578 \\
\hline Сумська & 734 & 703 & 703 & 703 & 703 & 703 \\
\hline Тернопільська & 564 & 564 & 564 & 564 & 564 & 564 \\
\hline Харківська & 1514 & 1521 & 1521 & 1520 & 1520 & 1520 \\
\hline Херсонська & 452 & 453 & 453 & 453 & 453 & 453 \\
\hline Хмельницька & 737 & 738 & 738 & 738 & 738 & 738 \\
\hline Черкаська & 588 & 588 & 588 & 588 & 588 & 588 \\
\hline Чернівецька & 413 & 413 & 413 & 413 & 413 & 413 \\
\hline Чернігівська & 856 & 851 & 851 & 851 & 851 & 851 \\
\hline Україна & 21684 & 20948 & 20954 & 20952 & 19770 & 19766 \\
\hline
\end{tabular}

*розраховано за даними Державної служби статистики України [1]

Дані таблиці 3 свідчать, що довжина автомобільних доріг загального користування за областями України в 2018 році порівняно з 2010 роком зменшилась на 4,5\%, в точу числі з твердим покриттям на 4,4 \%. Суттєвого збільшення або зменшення довжини автомобільних доріг загального користування за областями за аналізований період не спостерігалось.
Слід відмітити, що за останні 30 років у Європі швидкими темпами будувались автомагістралі міжнародного значення, в Україні щільність доріг у 5,9 разів менша, ніж у Франції. Протяжність швидкісних доріг в Україні становить 0,28 тис. км, у Німеччині - 10,9 тис. км, Франції - 7,1 тис. км. Незадовільним $€$ техніко-експлуатаційний стан автодоріг: 51,1 \% не відповідає вимогам за рівністю тих доріг, 39,2 \% - за міцністю [8]. 
Довжина автомобільних доріг загального користування за регіонами (на кінець року, тис. км)

\begin{tabular}{|c|c|c|c|c|c|c|c|c|c|c|}
\hline \multirow[b]{2}{*}{$\begin{array}{c}\text { Адміністративно-тери- } \\
\text { торіальні одиниці }\end{array}$} & \multicolumn{2}{|c|}{2010 рік } & \multicolumn{2}{|c|}{2015 рік } & \multicolumn{2}{|c|}{2016 рік } & \multicolumn{2}{|c|}{2017 рік } & \multicolumn{2}{|c|}{2018 рік } \\
\hline & Усього & $\begin{array}{c}\text { у т.ч. } 3 \text { твер- } \\
\text { дим покрит- } \\
\text { тям }\end{array}$ & Усього & $\begin{array}{c}\text { у т.ч. з твер- } \\
\text { дим покрит- } \\
\text { тям }\end{array}$ & Усього & $\begin{array}{c}\text { у т.ч. з твер- } \\
\text { дим покрит- } \\
\text { тям }\end{array}$ & Усього & $\begin{array}{c}\text { у т.ч. з твер- } \\
\text { дим покрит- } \\
\text { тям }\end{array}$ & Усього & $\begin{array}{c}\text { у т.ч. з твер- } \\
\text { дим покрит- } \\
\text { тям }\end{array}$ \\
\hline АР Крим & 6,3 & 6,3 & - & - & - & - & - & - & - & - \\
\hline Вінницька & 9,5 & 9,0 & 9,5 & 9,0 & 9,5 & 9,0 & 9,5 & 9,0 & 9,5 & 9,0 \\
\hline Волинська & 6,2 & 5,7 & 6,2 & 5,8 & 6,2 & 5,8 & 6,2 & 5,8 & 6,2 & 5,8 \\
\hline Дніпропетровська & 9,1 & 9,1 & 9,2 & 9,2 & 9,2 & 9,2 & 9,2 & 9,2 & 9,2 & 9,2 \\
\hline Донецька & 8,1 & 8,0 & 8,1 & 8,0 & 8,1 & 8,0 & 8,1 & 8,0 & 8,1 & 8,1 \\
\hline Житомирська & 8,5 & 8,3 & 8,5 & 8,3 & 8,5 & 8,3 & 8,5 & 8,3 & 8,6 & 8,4 \\
\hline Закарпатська & 3,3 & 3,3 & 3,3 & 3,3 & 3,3 & 3,3 & 3,3 & 3,3 & 3,4 & 3,4 \\
\hline Запорізька & 7,0 & 6,8 & 7,0 & 6,8 & 7,0 & 6,8 & 7,0 & 6,8 & 7,0 & 6,8 \\
\hline Івано-Франківська & 4,2 & 4,2 & 4,1 & 4,1 & 4,1 & 4,1 & 4,1 & 4,1 & 4,1 & 4,1 \\
\hline Київська & 8,5 & 8,5 & 8,6 & 8,6 & 8,6 & 8,6 & 8,6 & 8,6 & 8,7 & 8,6 \\
\hline Кіровоградська & 6,3 & 6,2 & 6,3 & 6,2 & 6,3 & 6,2 & 6,3 & 6,2 & 6,3 & 6,2 \\
\hline Луганська & 5,9 & 5,8 & 5,9 & 5,8 & 5,9 & 5,8 & 5,9 & 5,9 & 4,4 & 4,4 \\
\hline Львівська & 8,4 & 8,2 & 8,4 & 8,2 & 8,4 & 8,2 & 8,4 & 8,2 & 8,4 & 8,2 \\
\hline Миколаївська & 4,8 & 4,8 & 4,8 & 4,8 & 4,8 & 4,8 & 4,8 & 4,8 & 4,8 & 4,8 \\
\hline Одеська & 8,3 & 8,1 & 8,3 & 8,1 & 8,3 & 8,1 & 8,3 & 8,1 & 8,3 & 8,1 \\
\hline Полтавська & 8,9 & 8,9 & 8,9 & 8,9 & 8,9 & 8,9 & 8,9 & 8,9 & 8,9 & 8,9 \\
\hline Рівненська & 5,1 & 5,0 & 5,1 & 5,1 & 5,1 & 5,1 & 5,1 & 5,1 & 5,2 & 5,1 \\
\hline Сумська & 7,2 & 6,7 & 7,2 & 6,7 & 7,2 & 6,7 & 7,2 & 6,7 & 7,2 & 6,8 \\
\hline Тернопільська & 5,0 & 5,0 & 5,0 & 5,0 & 5,0 & 5,0 & 5,0 & 5,0 & 5,0 & 5,0 \\
\hline Харківська & 9,6 & 9,4 & 9,6 & 9,4 & 9,6 & 9,4 & 9,6 & 9,4 & 9,7 & 9,4 \\
\hline Херсонська & 5,0 & 5,0 & 5,0 & 5,0 & 5,0 & 5,0 & 5,0 & 5,0 & 5,0 & 5,0 \\
\hline Хмельницька & 7,2 & 7,1 & 7,2 & 7,1 & 7,2 & 7,1 & 7,2 & 7,1 & 7,2 & 7,1 \\
\hline Черкаська & 6,1 & 5,9 & 6,1 & 5,9 & 6,1 & 5,9 & 6,2 & 6,0 & 6,1 & 6,0 \\
\hline Чернівецька & 2,9 & 2,9 & 2,9 & 2,9 & 2,9 & 2,9 & 2,9 & 2,9 & 2,9 & 2,9 \\
\hline Чернігівська & 7,7 & 7,2 & 7,7 & 7,2 & 7,7 & 7,2 & 7,7 & 7,2 & 7,7 & 7,2 \\
\hline Севастополь & 0,4 & 0,4 & - & - & - & - & - & - & - & - \\
\hline Україна & 169,5 & 165,8 & 160,3 & 159,4 & 163,0 & 159,5 & 163,1 & 159,6 & 161,9 & 158,5 \\
\hline
\end{tabular}

*розраховано за даними Державної служби статистики України [1]

Висновки з даного дослідження і перспективи подальших розвідок у даному напрямку. Стан функціонування підприємств транспортної галузі України в цілому та її регіонів характеризується як кризовий. В умовах нестабільної політичної та економічної ситуації в Україні транспортні послуги втрачають певну долю на ринку послуг. Діяльність підприємств транспортної галузі регіону має бути спрямована на активізацію впровадження інноваційно-інвестиційної моделі розвитку, яка побудована на інноваційному оновленні матеріально-технічної бази галузі, використанні інноваційних технологій та методів в процесі управління. 3 метою створення конкурентоспроможної транспортної галузі регіону необхідно забезпечити надання якісних транспортних послуг, формування транспортної інфрраструктури і транспортних засобів, створення умов для перевищення рівня пропозиції транспортних послуг над попитом.

\section{Список використаної літератури:}

1. Транспорт і зв'язок України у 2019. Статистичний збірник. К. : Державна служба статистики України. 2020. 186 с.

2. Мохова Ю.Л. Значення транспортної галузі в системі національної економіки України. Менеджер. 2015. № 1 (69). С. 88-96.

3. Логутова Т. Г., Полторацький М.М. Сучасний стан транспортної інфраструктури України. Теоретичні і практичні аспекти економіки та інтелектуальної власності. 2015. Випуск 2(12). Т. 2. С. 8-14.

4. Результати діяльності Міністерства інфраструктури України за поточний період 2015 року. URL: https://mtu.gov.ua/timeline/?ry=2015

5. Боняр С.M., Корнійко Я.P. Аналіз роботи морських торговельних портів України.URL: http://www.maritime.kiev.ua/uploads/ Jurnal

6. Контейнерний каботаж - майбутнє річкової логістики. URL: http://ukrrichflot.ua/ua/novosti

7. Лагодієнко В.В., Корнієцький О.В. Логістика по-японськи: підвищення ефективності діяльності підприємств. Культура народов Причерноморья.- 2014.- №275.- С. 207-210.

8. Мироненко В.К. Прогноз обсягів перевезень залізничним транспортом на основі аналізу вантажоутворюючих галузей економіки для Львівської залізниці (напрямок Львів-Чоп). Київдніпротранс: електронне наукове фрахове видання. 2017. URL:http://www.kgt.ua/ uploads/file/Text.pdf

Mashkantseva S.O., PhD, Associate professor, Odesa National Maritime Academy (Odesa, Ukraine)

Economic diagnostics of the state and prospects of enterprises of the transport industry of the region

The article considers the state of activity of transport enterprises of the region by analyzing the indicators of cargo volume, 
cargo turnover, average distance of transportation, length of railways and public roads by regions. Measures to ensure the further development of transport enterprises at the regional level are proposed. It is substantiated that the current state of functioning of enterprises in the transport industry is characterized as a crisis, which significantly raises the issue of economic diagnostics of enterprises in the regions of Ukraine. This necessitates a meaningful analysis of the state of development of transport enterprises, identification of risk areas and the development of a set of anti-crisis measures.

Studies have shown that the transport sector occupies a special place in the development of all sectors of the economy, while ensuring the promotion of material flows in macro-logistics chains. The main task of the transport industry of the region is timely, highquality and full satisfaction of the needs of consumers (industries and population) in transportation, increasing the competitiveness of transport services. Over the past ten years, the state of the transport industry of Ukraine as a whole and its regions is characterized as unstable.

The study found that Ukraine should reform the river industry in order to transfer part of the flow of goods from roads and railways to rivers, as well as the development of river logistics and infrastructure. The country's authorities and leading companies of various forms of ownership, which are directly related to river transport, pay considerable attention to this issue, because the containerization of goods is, firstly, an unoccupied niche, and secondly, it is a global trend that has a steady trend to growth, and today is the most convenient and economical way of transportation due to its versatility, multimodality and reliability.

In the conditions of unstable political and economic situation in Ukraine transport services lose a certain share in the market of services. The activity of enterprises of the transport sector of the region should be aimed at intensifying the implementation of innovation and investment model of development, which is based on innovative updating of the material and technical base of the industry, the use of innovative technologies and methods in the management process. In order to create a competitive transport industry in the region, it is necessary to ensure the provision of quality transport services; formation of transport infrastructure and vehicles; creating conditions for exceeding the level of supply of transport services over demand.

Key words: cargo turnover, diagnostics, railway transport, road transport, transport branch, region, sea and river transport.

Дата надходження до редакції: 29.08.2019 р. 